\section{Dr W. M. Dale}

MANY workers in radiation research who were fortunate enough to draw on his advice lost a kind and understanding friend when Walter M. Dale, the founder and editor of the International Journal of Radiation Biology and Related Studies in Physics, Chemistry and Medicine, died on June 6.

Dale was born on September 23, 1894, in Berlin and died in Manchester where most of his scientific contributions were made. 'The First World War interrupted his studies in physics and muthematics. Iater he took up medicine and took degrees in both medicine and chemistry at Berlin University. He spont some time with Otto Warburg in Berlin and R. Willstätter in Munich. He was made Privatdozent in the Department of Medicine in the Medical Academy of Düsseldorf. Numerous early publications show that his interests moved from purely clinical and physiological topics to the more fundamental aspects of metabolism and enzymes. Many of his early papors already demonstrated his great inventiveness as an experimenter overcoming technical difficultics.

After coming to England in 1933 he worked in the Physiology Department of the University of Manchester where for a few years he collaborated with Professor H. S. Kaper on semi-clinical problems. But it was his appointment to the Christie Hospital and Holt Radium Institute in 1936 that gave him the challenge he needed. In this new environment he started as a lonely worker to disentangle the effects of ionizing radiations on solutions of cnzymes and other solutes. He became one of the pioneers of radiation chemistry and was successful in recognizing and formulating what is now known as the indirect effect of ionizing radiation when he demonstrated the kinetics of enzyme destruction by radiation-produced free radicals in the aqucous medium. The now classical experiments with $\alpha$-rays on carboxypeptidase, in collaboration with W. J. Meredith and I. H. Gray, led to a confirmation and a better understanding of D. E. Lea's theory of the track structure of an ionizing particle in liquid water. Dale's interest was attracted to the possibility of protecting biomolecules in solution by the addition of competing radical scavengers, which led directly to the investigation of compounds which contain sulphur. This marked the beginning of many investigations in many laboratories on protection in radiation biology. He contributed substantially to the early studies of radiation-induced deamination reactions of amino-acids and proteins, a topic which is still pursued actively in several laboratories here and abroad.

In 1958 he founded the International Journal of Radiation Biolngy at a time when such an interdisciplinary medium was needed urgently. His firm editorship was of great service to the rapidly growing field of radiation research.

\section{Correspondence}

\section{Framework for Forward Planning}

Sir,-Your article dealing with the role of the Canadian Government in rescarch at universities (Nature, 222, 1024; 1969 ) is accurato but does not point out a serious fault.

In my particular area, ehemistry, government support, as seen by the size and cquipment of departments across Canada, is excellent. But this support is given without any consideration of the necds of Canada. The PhDs produced have become a by-product of the rescarch, having little use to Canada.

Industrial and university positions are searce and greatly exceeded by the number of $\mathrm{PhD}$ s graduating. $\mathrm{I}_{n}$ addition, the industrial posts are usually filled by industrially experienced men from the USA because the companies refuse the expense of paying a recent graduate for the three or more years it takes for him to become industrially useful. The government's money which is spent to train these $\mathrm{PhDs}$ is wasted.

It appears obvious that a closer look at research in Canada is needed, to find those areas where research benefits Canada rather than those areas where the number of published papers per research dollar is high.

$$
\text { Yours faithfully, }
$$

Christopher H. MatThews

602-3474 Hutchinson Street,

Montreal 130, PQ,

Canada.

\section{University News}

Dr John W. Midgley, English Electric Company, Limited, has been appointed as first director of the new Centre for Industrial Consultancy and Liaison at the University of Edinburgh. The centre is intended to develop all forms of mutually protitable university-industry collaboration.

Dr J. K. Sutherland, who was recently appointed to the chair of organic chemistry at Heriot-Watt University, has for personal reasons withdrawn from the appointment. Professor J. H. Kellgren, professor of rheumatology and director of the Rheumatism Research Centre, has been appointed Pro-Vice-Chancellor at the University of Manchester, in succession to Professor A. C. P. Campbell.

Dr Bernard John, University of Birmingham, has been appointed to the chair of zoology at the University of Southampton.

The following appointments to foundation chairs in the new medical school at the University of Southampton have been made: Mr D. G. Millar, University of Newcastle upon 'Iyne, has been appointed to the foundation chair of clinical science in human reproduction ancl obstetrics; Dr J. B. L. Howell, University of Manchester, to the foundation chair of clinical science in medicine; Sir James Fraser, University of Fdinburgh, to the foundation chair of clinical science in surgery; and Dr D. Bulmer, University of Manchester, to tho foundation chair of pre-clinical science in human morphologs. Dr Dorothy M. Horstmann has been appointed as the first incumbent of the John Rodman Paul professorship of epidemiology at the Yale School of Medicine.

\section{Announcements}

The MRG Laboratory Animals Centre at Carshalton, Surrey, has appointed Mr K. R. Hobbs as a primate officer. He will be carrying out a detailed investigation into the existing provision, use and future need of laboratory primates for research. Information can be obtained from $\mathrm{Mr}$ Hobbs, telephone number 01-643 4461.

The International Meteorological Organization Prize has been awarded by the World Meteorological Organization Committee to Professor E. H. Palmen, University of Holsinki, in recognition of his contribution to the knowledge of the movement of weather systoms in all latitudes and at all levels of the troposphere.

The International Feltrinelli Medical Award has been given this yoar to Dr Rita Levi-Montalcini, Washington University, for her rescarch achievements in neurobiology. 